\title{
Structural and Typological Features of the Axiological Aspect of Modern Students' Representation about Success
}

\author{
Igor A. Alikin ${ }^{a}$, Larisa V. Dovydenko ${ }^{b}$ \\ and Natalia V. Lukyanchenkob* \\ ${ }^{a}$ Krasnoyarsk State Pedagogical University \\ named after V.P. Astafiev Krasnoyarsk, Russian Federation \\ ${ }^{b}$ Reshetnev Siberian State University of Science \\ and Technology Krasnoyarsk, Russian Federation
}

Received 03.07.2019, received in revised form 10.10.2019, accepted 21.10.2019

\begin{abstract}
Currently, one of the leading orientations for determining the quality of life in many young minds is achieving success. The focus on success is the basis of achievement motivation, which activity is a psychological factor for economic growth, and this fact determines its high social significance. Psychologically competent provision of conditions for the productive implementation of pursuit for success implies understanding of its axiological aspect. A study of structural and typological features of the axiological aspect of modern students' representation about success has been conducted. Respondents are 591 students of Krasnoyarsk universities. Methodology by S.A. Pakulina "Students' Motivation to Achieve Success in University" has been applied. Data processing included descriptive statistics, correlation, factor and cluster analysis, as well as identification of significant differences. According to the study results, students' representation of success is based on a wide range of values. At the same time, the values of interiorized (internally represented) success are of great importance for both humanitarian and technical students. The significance levels of various value aspects of success are interconnected in a positive way. The overall level of success values' significance is determined by the cumulative effect of subjective and personal values, as well as values of social importance. In accordance with this, the strategy of developing psychological tools to help students in the productive implementation of the pursuit for success, should include formation of social interest, development of individual strategies for the implementation of social utility and skills for obtaining positive feedback in the process of achieving goals.
\end{abstract}

Keywords: success, interiorized success, exteriorized success, values, representation, students, humanitarian specialties, technical specialties.

Research area: socio-psychological personality traits.

\footnotetext{
(C) Siberian Federal University. All rights reserved

* Corresponding author E-mail address: alikinia@mail.ru, Luk.nv@mail.ru ORCID: 0000-0001-9787-1512 (Alikin); 0000-0003-2813-9461 (Lukyanchenko)
} 
Citation: Alikin, I.A., Dovydenko, L.V., Lukyanchenko, N.V. (2022). Structural and typological features of the axiological aspect of modern students' representation about success. J. Sib. Fed. Univ. Humanit. Soc. Sci., 15(3), 372-380. DOI: 10.17516/1997-1370-0468.

\section{Introduction}

The issue of success has become a kind of a marker of the current state of young Russians' mindset and a trend of different levels of discourses. Success is discussed as an orientation and criterion of the quality of life. The category of success has acquired the meta-level characteristics, becoming a motivational meme of unprecedented significance, which must be taken into account when developing forms of psychological support for the optimal implementation of human resource in the modern society. Psychology can and should respond to this challenge of modernity. However, the analysis of the current state of psychological practice indicates that this response is of a spontaneous, or one might say, "market" nature. Populist programmes about "the secrets of success" are in high demand. Their promises mesmerize young people striving to obtain samples of life productivity. There is a vivid shortage of scientifically and empirically grounded psychological technologies that meet this interest.

The young generation potential is actively studied in the aspect of communication (Lee et al., 2012; Proctor et al., 2009; Rentzsch et al., 2011; Robinson, 2008; Rudawska, Szarek, 2014), personal (Kauffman, Husman, 2014; Suleyman, 2013), and cognitive (Ziegler, Stoeger, 2011) characteristics. Along with this, the field of study on the perception of social reality and the possibilities of self-determination by young people is being formed (Alexander, 2013; Kondratyev, 2017; Rean, 2018; Timoshina, 2016; Folomeeva, Fedotova, 2018). And consideration of value perception of success by university students by S.A. Pakulina (Pakulina, 2008), connected with the motivation of achievement, is of specific interest. This perception is highly relevant, since extraordinary significance of success orientations for young people can be seen as the potential for increasing achievement motivation. And, as demonstrated in a series of large-scale social studies by D.C. McClelland, such an increase is a necessary condition for economic growth (McClelland, 1987). As a popular subject of study in Western psychology, achievement motivation was mainly studied in its dynamic aspect and under laboratory conditions (Heckhausen, 2003). Achievement motivation is focused on achieving success as a positive result of activity. But, if under laboratory conditions success is determined by the characteristics of an experimental assignment, in real life this orientation is mostly a subjective assessment. And not only from the point of view of levels, but in the value criteria basis as well. The axiological component of the subjective perception of success determines what exactly is significant for a person in his/ her assessment of the quality of life. According to N.A. Baturin, success orientations are global mechanisms that affect the need and motivational basis of activity, they affect the choice, initiation and regulation of a person's activity. This assessment is of complex nature and originates simultaneously from a system of bases of different content and nature (Baturin, 1999). In this connection, S.A. Pakulina indicates that "... success is not only a phenomenal object that is qualitative in relation to the result, and not only the result itself, but, above all, its assessment and the meaning for existence for an actor who forms the substantive basis of a person's motivational sphere" (Pakulina, 2008: $25)$. This refers to the value-based content of the idea of success.

On the one hand, the axiological problematics in psychology is focused on the study of basic values of a person (Schwartz, 2015). On the other hand, a lot of researchers pay attention to the fact that value orientations in modern society have seriously changed even compared to the recent past (Zhuravleva, 2006; Rzhanova, Alekseeva, 2018; Fedotova, 2016; Lönnqvist et al., 2018; Tulviste et al., 2014).

In connection with the above, a study of structural and typological features of the axiological aspect of the representation of modern students about success has been conducted. 


\section{Methods}

Students of Krasnoyarsk State Pedagogical University named after V.P. Astafyev, Reshetnev Siberian State University of Science and Technology and Siberian Federal University took part in the study. The total number of respondents is 591 people, 315 of which are students of humanitarian specialties and 276 are of technical specialties; 233 young men and 358 young women.

Methodology by S.A. Pakulina "Students' Motivation to Achieve Success in University" (Pakulina, 2008) was used in the study. Although the name of the methodology is formulated in motivational terms, according to the author's definition, as well as the essence of the procedure, it is aimed to determine value preference for different aspects of success among students. In the process of S.A. Pakulina's methodology development by a multi-stage analysis, which includes processing of students' essays and questionnaires in connection to the provisions of famous researchers (H. Heckhausen, Yu. M. Orlov, G.A. Tulchinsky and McDougall), a list of 36 statements beginning with the words "For me success is ..." was formed. The respondents are asked to assess the significance of each of them according to a five-point scale. These judgments reflect "key categories of motives for achieving success" identified by the author and grouped together into exteriorized and interiorized success groups (Pakulina, 2008).

The exteriorized orientation of the idea of success corresponds to the following categories: success-luck (successful achievement of a desired goal, a favorable set of circumstances, luck in most cases, the possibility to get into the right environment); material standard of living (material well-being, the possibility to travel around the world, personal well-being, having one's own business in entrepreneurship); recognition (ability to stand out in society, public recognition, approval, popularity, importance for others); power (influence on others, the possibility to manage people, recognition of own authority by others, the ability to make decisions for other people).

The interiorized orientation of the idea of success corresponds to: success as a result of one's own activity (implementation of an opportunity to do what you want, positive result in studies or work, professionalism, expertise, achievement of the expected result); personal success (self-esteem, self-satisfaction, confidence in security, personal fulfillment, satisfaction in love and health); success as a mental state (experiencing satisfaction and joy, peace of mind, emotional stability, feeling good, good mood, feeling of positive emotional uplift); success as overcoming obstacles (a stable position of an individual in a particular situation, self-affirmation, a source of human inner power, self-sufficiency, independence, freedom of action); success-mission (the opportunity to express oneself and one's abilities to the full extent, self-expression in creative work, service to a higher idea, activity after one's heart, an interesting job).

The research data processing included descriptive statistics (determination of mean values and ranking), correlation analysis with the use of the Spearman coefficient, factor analysis, cluster analysis (using the nearest neighbor algorithm in Euclidean space), and identification of significant differences using the Mann-Whitney U-test.

\section{Research results}

To determine comparative significance of different value components of the representation of success mean values of their indicators among students of humanitarian and technical specialties were calculated and ranked (Table 1).

Hierarchies of value aspects of success are similar among students of different fields of education. Internal values are of greater significance (interiorized success). "Success-power" and "success-recognition" are of the least significance. Personal success takes the first place in the "competition" for the top two among students of humanitarian specialties, and value "success as a result of one's own activity" takes the second place. Success as a result of one's own activity is prioritized among students of technical specialties. In other words, for students of humanitarian specialties the most valuable manifestation of success is personal confidence, a sense of high "quality of person- 
Igor A. Alikin, Larisa V. Dovydenko,.. Structural and Typological Features of the Axiological Aspect of Modern...

Table 1. Ranked hierarchy of mean values of success values significance indicators

\begin{tabular}{|c|c|c|}
\hline \multirow{2}{*}{ Rank } & \multicolumn{2}{|c|}{ Comparison groups } \\
\hline & Humanitarian students & Technical students \\
\hline 1 & Personal success 17.1 & Success as activity result 17 \\
\hline 2 & Success as activity result 16.7 & Personal success 16.8 \\
\hline 3 & Success as a mental state 16.5 & Success as a mental state 16.4 \\
\hline 4 & Success as overcoming obstacles 16 & Success as overcoming obstacles 16.1 \\
\hline 5 & Success-mission 15.7 & Success-luck 15.6 \\
\hline 6 & Success as material standard of living 15.4 & Success-mission 15.4 \\
\hline 7 & Success-luck 15.2 & Success as material standard of living 15.4 \\
\hline 8 & Success-recognition & Success-recognition 13.4 \\
\hline 9 & Success-power 11.1 & Success-power 11.7 \\
\hline
\end{tabular}

Table 2. Correlation of success values significance indicators among students

\begin{tabular}{|c|c|c|c|c|c|c|c|c|c|c|c|}
\hline & 弟 & 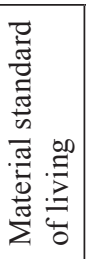 & 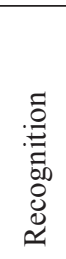 & $\begin{array}{l}\dot{\overline{0}} \\
\vdots \\
0 \\
0\end{array}$ & 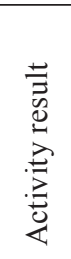 & 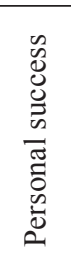 & 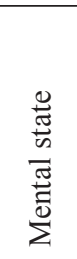 & 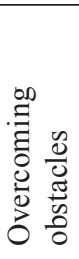 & 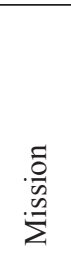 & 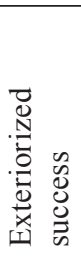 & 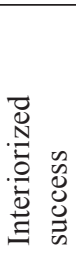 \\
\hline Luck & & 0.42 & 0.43 & 0.38 & 0.40 & 0.37 & 0.39 & 0.41 & 0.28 & 0.68 & 0.48 \\
\hline Material standard of living & 0.42 & & 0.43 & 0.43 & 0.47 & 0.50 & 0.34 & 0.46 & 0.33 & 0.70 & 0.53 \\
\hline Recognition & 0.43 & 0.43 & & 0.67 & 0.33 & 0.33 & 0.22 & 0.37 & 0.28 & 0.84 & 0.39 \\
\hline Power & 0.38 & 0.43 & 0.67 & & 0.30 & 0.23 & 0.09 & 0.37 & 0.20 & 0.83 & 0.31 \\
\hline Activity result & 0.40 & 0.47 & 0.33 & 0.30 & & 0.51 & 0.42 & 0.53 & 0.42 & 0.46 & 0.74 \\
\hline Personal success & 0.37 & 0.50 & 0.33 & 0.23 & 0.51 & & 0.56 & 0.54 & 0.46 & 0.43 & 0.80 \\
\hline Mental state & 0.39 & 0.34 & 0.22 & 0.09 & 0.42 & 0.56 & & 0.47 & 0.44 & 0.30 & 0.76 \\
\hline Overcoming obstacles & 0.41 & 0.46 & 0.37 & 0.37 & 0.53 & 0.54 & 0.47 & & 0.39 & 0.50 & 0.75 \\
\hline Mission & 0.28 & 0.33 & 0.28 & 0.20 & 0.42 & 0.46 & 0.44 & 0.39 & & 0.33 & 0.72 \\
\hline Exteriorized success & 0.68 & 0.70 & 0.84 & 0.83 & 0.46 & 0.43 & 0.30 & 0.50 & 0.33 & & 0.53 \\
\hline Interiorized success & 0.48 & 0.53 & 0.39 & 0.31 & 0.74 & 0.80 & 0.76 & 0.75 & 0.72 & 0.53 & \\
\hline
\end{tabular}

ality", while for technical students - in quality and effectiveness of the activities performed.

The procedure for identifying significant differences determined a significantly greater importance (95\%) of personal success, success-mission and less significance of luck, power and overall exteriorized success rate for students of humanitarian specialties compared to students of technical specialties.

All the indicators obtained in the study were included into the correlation analysis, which results are given in Table 2 .
Significance levels:

- 0.0807 for $95 \%$ of the correlation coefficient significance level $(\mathrm{p}<0.05)$;

- 0.1060 for $99 \%$ of the correlation coefficient significance level $(\mathrm{p}<0.01)$.

The overall picture of correlation links has a unique feature: all the indicators are connected with all other indicators by significant positive links. There are no negative links. This means that no axiological aspect of success is opposed to another. The level profile of success values significance can be either generally 
higher or lower. In the context of the fact that at the theoretical level different success value orientations are opposed to each other, this empirical fact is of interest. Only values of mental state and power have very low, close to the lower limit of significance correlation coefficient.

The factor analysis of the data obtained allowed to determine two factors, covering a total of $61.8 \%$ of dispersion (the first is $47.3 \%$, and the second one is $14.5 \%$ ). Factor weights of the indicators were distributed as follows.

Factor 1: mental state 0.81 ; personal success 0.807 ; overcoming obstacles 0.69 ; mission 0.68 ; activity result 0.66 ; material standard of living 0.53 ; luck 0.45 ; recognition 0.17 ; power 0.06 .

Factor 2: power 0.90 ; recognition 0.84 ; luck 0.511; material standard of living 0.50 ; overcoming obstacles 0.35 ; activity result 0.31 ; personal success 0.18 ; mission 0.12 .

It is worth noting that the identified factors practically reflect each other. Considering the factor weights, it is possible to distinguish three groups of indicators in each of the factors. Such indicators of success significance as overcoming obstacles, material level, activity result and luck have average weights in both factors. Success as a mental state and personal success have large weight in the first factor, in contrast to the second one, where they occupy the least positions. Such indicators of success as power and success-recognition, which do not play a significant role in the first factor, have large weights in the second factor. Only such an indicator as success-mission has an average weight in the first factor and close to zero in the second one.

In the opinion of the authors of the present paper, such data can be interpreted in the following way: there is a kind of a core in the students' sampling of the axiological aspect of success (overcoming obstacles, a material standard of living, activity result and luck), which can be found at the point of confluence of two relatively independent sources: subjective and personal values (mental state and personal success) and values of social significance (power and recognition).

The cluster analysis gave an opportunity to identify 4 groups of respondents, opposing to each other in their perception of success values significance. The first of them included 249 people ( $42 \%$ of the sampling), the second group included 242 people (41\%); the third one 78 people (13\%); and the fourth group 22 people $(4 \%)$. The average values of the studied parameters in each of the groups are presented in Table 3.

The selected groups can be divided into two pairs according to the features of the axio-

Table 3. Average group values for the indicators of success values significance

\begin{tabular}{|c|l|c|c|c|c|}
\hline \multirow{2}{*}{ No. Values } & \multicolumn{4}{c|}{ Groups } \\
\cline { 3 - 6 } & & 1 & 2 & 3 & 4 \\
\hline 1 & Success-luck & 15.2 & 16.8 & 12.9 & 12 \\
\hline 2 & Success as material standard of living & 14.8 & 16.9 & 13.2 & $\mathbf{1 2 . 4}$ \\
\hline 3 & Success-recognition & 13 & 14.8 & 9.3 & 11.1 \\
\hline 4 & Success-power & 11.3 & 13 & 7.3 & 10 \\
\hline 5 & Success as result of one's own activity & $\mathbf{1 6 . 3}$ & $\mathbf{1 8 . 1}$ & 15.3 & $\mathbf{1 3 . 9}$ \\
\hline 6 & Personal success & $\mathbf{1 6 . 2}$ & $\mathbf{1 8 . 3}$ & $\mathbf{1 6 . 4}$ & 11.4 \\
\hline 7 & Success as a mental state & 15.7 & 17.9 & $\mathbf{1 6 . 1}$ & 10.5 \\
\hline 8 & Success as overcoming obstacles & 15.2 & 17.6 & 15 & 12 \\
\hline 9 & Success-mission & 14.6 & 16.8 & 15.6 & 11.8 \\
\hline 10 & Exteriorized success & 67.8 & 76.9 & 53.4 & 56.8 \\
\hline 11 & Interiorized success & 78 & 88.8 & 78.4 & 59.6 \\
\hline
\end{tabular}

Note: the highest indicator values in the group are in bold; the third in their importance are in italics with underlining; the lowest values are in italics. 
logical profiles that characterize them: the first and the second groups; the third and the fourth groups.

The first pair of the respondents group has higher indicators of the success values significance compared to the second group. And inside the pair they are higher in the second group compared to the first one. Herewith, the indicators hierarchy is similar. The first two places are occupied by the indicators "success as a result of one's own activity" and "personal success." The third place is taken by the indicator "success as a mental state". The exteriorized success values are assessed as less significant. The success-power value has the lowest indicator.

The first pair of the respondents group has higher indicators of the success values significance compared to the second group. And inside the pair they are higher in the second group compared to the first one. Herewith, the indicators hierarchy is similar. The first two places are occupied by the indicators "success as a result of one's own activity" and "personal success." The third place is taken by the indicator "success as a mental state". The exteriorized success values are assessed as less significant. The success-power value has the lowest indicator.

For the third group of respondents, the subjective aspects of success, which are quite far from its external, social manifestations (personal success, success as a mental state, and success-mission) are of special significance. The exteriorized success values (success-power and success-recognition) have the lowest indicators among all groups. The levels of indicators related to the "value core" of success correspond to the conditional third place in the intergroup comparison: higher than in the fourth group, but lower than in the first and second groups.

The fourth group of respondents is characterized by the lowest indicators of success values significance. In can be said that its instrumental orientation is its peculiarity. The exteriorized success values (success-recognition and success-power) are more important for the respondents of this group than for the third one. At the same time, in comparison with oth- er groups, the significance of success as a mental state and other internalized values is very low. Success as overcoming obstacles, success as activity result and success as a material standard of living are prioritized.

As can be seen, the comparative analysis demonstrates that the respondents' groups with low indicators of subjective and personal values or social significance values are characterized by a reduced level of all value aspects of success. This can be considered as a confirmation of the fact that success significance as a whole is determined by the cumulative effect of the values of subjective experience of success and social significance values.

Conclusions. Students' representation of success is of poly-axiological nature and its core includes a wide range of values.

For both students of humanitarian and technical specialties, the interiorized success values are of great importance. At the same time, for students of humanitarian specialties, compared to students of technical specialties, this value indicator is higher.

The levels of various success value aspects significance are positively interconnected. The significance of different values does not contradict each other. The cumulative profile of success values significance has a general tendency level.

The success values can be divided into the "value core" (overcoming obstacles, the result of one's own activity, material standard of living and luck), subjective and personal values (mental state and personal success) and social significance values (power and recognition).

The overall level of success values significance is determined by the cumulative effect of subjective and personal values, as well as values of social significance. Reduction in both values entails a decrease in the level of the entire success value profile.

The study data give an opportunity to determine the strategy for developing psychological tools to help students in the productive implementation of their pursuit for success, which include: social interest formation, development of individual strategies for the implementation of social utility and skills for obtaining positive feedbacks in the process of achieving goals. 


\section{References}

Alexander, J. (2013). Smysly sotsial'noi zhizni: Kul'tursotsiologiia [Meanings of Social Life: Cultural Sociology]. Moscow, Praksis, 640 p.

Baturin, N.A. (1999). Psikhologiia uspekha i neudachi [Psychology of Success and Failure]. Chelyabinsk, YUUrGU, 100 p.

Fedotova, V.A. (2016). Vzaimosviaz' tsennostei i innovativnykh ustanovok u predstavitelei raznykh pokolenii rossiian [Values and Attitudes towards Innovation among Different Generations of Russian People]. In Sotsial'naia psikhologiia i obshchestvo [Social Psychology and Society], 7(2), 82-92. DOI: 10.17759/ sps.2016070206.

Folomeeva, T.V., Fedotova, S.V. (2018). Differentsiatsiia obrazov vysokostatusnogo i nizkostatusnogo cheloveka u molodezhi [Images Differentiation of High Status and Low Status Person Among Young People]. In Sotsial'naia psikhologiia i obshchestvo [Social Psychology and Society], 9(3), 197-207. DOI: 10.17759/sps.2018090319.

Heckhausen, H. (2003). Motivatsiia i deiatel'nost' [Motivation and Action]. Sankt-Peterburg, Piter; Moskow, Smysl, 860 p.

Kauffman, D.F., Husman, J. (2014). Effects of Time Perspective on Student Motivation: Introduction to a Special Issue. In Educational Psychology Review, 16(1), 1-7. DOI: 1023/B:EDPR.0000012342.37854.58.

Kondratyev, M.D. (2017). Sotsial'nye predstavleniia ob uspeshnosti podrostkov s raznym intragruppovym statusom i raznym urovnem intellektual'noi uspeshnosti [Social Representations about Teenagers Success with Different Intragroup Status and Different Levels of Intellectual Success]. In Sotsial'naia psikhologiia i obshchestvo [Social Psychology and Society], 8(2), 116-130. DOI:10.17759/sps.2017080208.

Lee, S.Y., Olszweski-Kubilius, P., Thomson, D. (2012). Academically Gifted Students' Perceived Interpersonal Competence and Peer Relationships. In Gifted Child Quarterly, (56), 90-104.

Lönnqvist, J.-E., Leikas, S., Verkasalo, M. (2018). Value Change in Men and Women Entering Parenthood: New Mothers' Value Priorities Shift Towards Conservation Values. In Personality and Individual Differences, (120), 47-51.

McClelland, D.C. (1987). Human Motivation. New York, New Rochelle, Melborne, Sidney: Cambridge University Press.

Pakulina, S.A. (2008). Psikhologicheskaia diagnostika motivatsii dostizheniia uspekha studentov v vuze [The Psychodiagnostics of Achievement Motivation of Students]. In Izvestiia Rossiiskogo gosudarstvennogo pedagogicheskogo universiteta im. A.I. Gertsena [Izvestia: Herzen University Journal of Humanities \& Sciences], (88), 23-32.

Proctor, C., Linley, P.A., Maltby, J. (2009). Youth Life Satisfaction: A Review of the Literature. In Journal of Happiness Studies, 10 (5), 583-630. DOI: 10.1007/s10902-008-9110-9.

Rean, A.A., Konovalov, I.A. (2018). Sotsial'no-pertseptivnyi obraz razlichnykh sotsial'nykh grupp v soznanii podrostkov [Adolescent's Socio-Cognitive Representations (Images) of Different Social Groups]. In Sotsial'naia psikhologiia i obshchestvo [Social Psychology and Society], 9(2), 60-80. DOI:10.17759/ sps.2018090205.

Rentzsch, K., Schütz, A., Schröeder-Abé, M. (2011). Being Labeled Nerd: Factors That Influence the Social Acceptance of High-Achieving Students. In The Journal of Experimental Education, (79), 143-168.

Robinson, N.M. (2008). The Social World of Gifted Children and Youth. In Handbook of Giftedness in Children: Psychoeducational Theory, Research and Best Practices. New York: Springer, 33-51.

Rudawska, A., Szarek, M. (2014). Students' Attitudes Towards Teamwork and Their Group Effectiveness. In E-mentor, 3 (55), 12-21. DOI: 10.15219/em55.1104.

Rzhanova, I.E., Alekseeva, O.S. (2018). Tsennostnye predpochteniia dvukh pokolenii [Value Preferences of Two Generations]. In Psikhologicheskie issledovaniia [Psychological Studies], 11 (60), 6. Available at: $\underline{\text { http://psystudy.ru }}$

Suleyman, A. (2013). Relations Between Self-Regulation. Future Time Perspective and the Delay of Gratification in University Students. In Education, 133 (4), 525-537. 
Schwartz, S.H. (2015). Basic Individual Values: Sources and Consequences. In Handbook of Value, Oxford: Oxford University Press. DOI: 10.1093/acprof:oso/9780198716600.003.0004.

Timoshina, I.N. (2016). Struktura sotsial'nykh predstavlenii studentov o statuse v sovremennom obshchestve [The Structure of Students' Perception of Social Status in Contemporary Society]. In Sotsial'naia psikhologiia i obshchestvo [Social Psychology and Society], 7 (2), 51-64. DOI: 10.17759/sps.2016070204.

Tulviste, T., Konstabel, K., Tulviste, P. (2014). Stability and Change in Value Consensus of Ethnic Estonians and Russian-Speaking Minority. In International Journal of Intercultural Relations, (39), 93-102.

Ziegler, A., Stoeger, H. (2011). Expertisierung als Adaptions- und Regulationsprozess: Die Rolle von Bildungs- und Lernkapital [The Role of Adaptation and Regulation Processes in the Acquisition of Excellence: The Role of Educational and Learning Capital]. In Motivation, Selbstregulation und Leistungsexzellenz (Talentförderung - Expertisenentwicklung - Leistungsexzellenz, Band [Motivation, Self-Regulation, and Excellence (Promoting Talent - Developing Expertise - Achieving Excellence)], Muenster: LIT, (9), 131-152.

Zhuravleva, N.A. (2006). Dinamika tsennostnykh orientatsii molodezhi v usloviiah sotsial'no-ekonomicheskikh izmenenii [Dynamics of Value Orientations of Youth under Conditions of Social and Economic Changes]. In Psikhologicheskii zhurnal [Psychological Journal], 27 (1), 35-43. 


\title{
Структурные и типологические особенности аксиологического аспекта \\ представления современных студентов об успехе
}

\author{
И.А. Аликина, Л.В.Довыденко ${ }^{6}$, Н.В. Лукьянченко \\ ${ }^{a}$ Красноярский государственный педагогический \\ университет им. В.П. Астафьева \\ Российская Федерачия, Красноярск \\ ${ }^{6}$ Сибирский государственный университет науки \\ и технологий им. академика М.Ф. Решетнева \\ Российская Федерачия, Красноярск
}

\begin{abstract}
Аннотация. В настоящее время одним из ведущих ориентиров определения качества жизнедеятельности в сознании многих молодых людей выступает достижение успеха. Ориентация на успех лежит в основе мотивации достижения, активность которой является психологическим фактором экономического подъема, что определяет ее высокую общественную значимость. Психологически грамотное обеспечение условий продуктивной реализации стремления к успеху предполагает пониманиеегоаксиологическогоаспекта.Былопроведеноисследованиеструктурных и типологических особенностей аксиологического аспекта представления современных студентов об успехе. Респонденты - студенты красноярских вузов в количестве 591 человека. Использована методика С.А. Пакулиной «Мотивация достижения успеха студентов в вузе». Обработка данных включала описательную статистику, корреляционный, факторный и кластерный анализ, выявление достоверных различий. Результаты исследования показали, что представление студентов об успехе содержит в своей основе широкий диапазон ценностей. При этом большую значимость для студентов как гуманитарных, так и технических специальностей имеют ценности интериоризованного (внутренне представленного) успеха. Уровни значимости различных ценностных аспектов успеха взаимосвязаны друг с другом положительным образом. Общий уровень значимости ценностей успеха задается совокупным действием субъективно-личностных ценностей и ценностей социальной значимости. В соответствии с этим стратегия разработки психологических средств помощи студентам в продуктивной реализации стремления к успеху должна включать формирование социального интереса, выработку индивидуальных стратегий реализации социальной полезности и навыков получения положительной обратной связи в процессе достижения поставленных целей.
\end{abstract}

Ключевые слова: успех, интериоризованный успех, экстериоризованный успех, ценности, представление, студенты, гуманитарные специальности, технические специальности.

Научная специальность: 19.00.05 - социальная психология. 